\section{Grave Threat to N.H.S.}

Last week saw the gravest threat to the N.H.S. in the twentysix years of its history. The deplorable turn of events in the Owen Working Party threatens doctors and patients alike: for the former it promises time wasted in bickering and soured relations with employers; for the latter an inevitable decline in standards of medical care.

Mrs. Castle's conduct in so peremptorily ending the Owen Working Party on 20 December suggests that she is allowing ideology to suffocate common sense. The Secretary of State has destroyed the remnants of her negotiating credibility among doctors and endangered the N.H.S. as well.

Soon after taking office Mrs. Castle set up-with the profession's support-the joint professional/departmental working party to overcome the negotiating impasse over new contracts for N.H.S. consultants. Despite some stormy passages the discussions were making some progress. Then on 12 December at a few hours notice the Government deferred a planned meeting - ostensibly to allow time for more internal Whitehall consultations.

On 20 December Mrs. Castle presented a take-it-or-leave-it contract package (see summary p. 45) which she must have known would be unacceptable to the consultants. After a tempestuous three-hour session the B.M.A.'s representatives decided that they had no option but to recommend consultants to work to contract from the New Year, a stand supported by the Hospital Consultants and Specialists Association Council's meeting next day. Indeed, some senior hospital staff were sufficiently incensed to start such action before Christmas.

There were two principal reasons for this unprecedented step: the contents of the non-negotiable package and the way it was presented. The Government's revised contract would offer little if any improvement over its original unacceptable proposals, which earlier had nearly wrecked the working party (16 November, p. 426). Indeed, most of the concessions subsequently offered by Dr. David Owen-which had influenced the decision by the C.C.H.M.S. to continue discussions (16 November, p. 416)-are missing from the Castle contract. The Government, for instance, still insists on giving a "two-session advantage" as an inducement to wholetime consultants. Its obduracy in defending this proposal looks illogical in the face of preliminary (unpublished) survey evidence gathered for the working party. This suggests that on average part- and whole-time consultants each devote about the same amount of their time to the N.H.S. - around 115 hours a week (including on call liabilities). Other aspects of the Government's package would favour further those doctors signing on full time. The offer of extra sessions first to wholetimers is back in the revised proposals, and career supplements, while open to all, would be subject to a means test of private earnings for part-time consultants. The part-timers' session allowance for travel will be withdrawn and an item-of-service contract is now ruled out as too expensive.

All this will convince many doctors that this Government is determined to take consultants into a whole-time State salaried service-with all that that implies for medicine (16 November, p. 363). Mrs. Castle acknowledged this objective in her intervention in the negotiations on 20 December. But it was also the manner of her intervention that angered the profession's representatives. For an employer to present, as she did, detailed proposals for a new contract to staff representatives only $\mathbf{3 0}$ minutes before a meeting and then declare that the package is not for negotiation smacks of the worst aspects of Victorian paternalism.

Furthermore, the Secretary of State clearly doubts whether the B.M.A. and the H.C.S.A. represent consultants-for she has posted details of her package directly to all consultants. In fact, both organizations have taken considerable trouble (including questionnaires) to obtain the views of their constituents and the negotiators have presented these consistently. Perhaps the criticism by some whole-time consultants of the profession's 10-session contract proposals has convinced the Secretary of State that she can readily "divide and rule." Are junior staff expected to step forward and fill any gaps in the N.H.S. created by a work-to-contract? With the juniors' own contract negotiations bogged down this would be wishful thinking. General practitioners have already declared their support for the consultants' fight for a fair contract (30 November, p. 545). So if the consultants form a united front Mrs. Castle's reported boast to sit out any confrontation for several months if necessary will be sorely tested.

By working a "contract week" and offering their services through a B.M.A. agency for any additional hours needed by hospitals the consultants will have done their best to ensure the minimum inconvenience to patients. It has been reported that the Health Departments have instructed health authorities not to employ doctors outside contract hours, but all emergencies will, in any case, be treated. Nevertheless some consultants will still oppose industrial action. Only if convinced that the Government's intransigence will in the long run harm both their patients and the N.H.S., as well as compromising professional independence will they countenance it, and then only as a last resort.

The profession's negotiators have sought three simple objectives: to close the present open-ended contract; to guarantee an adequate reward for work done for the N.H.S.; and to allow consultants to do as they wish with their free time. The Government plan appears to fulfil the first aim only. Whole-time consultants may be dazzled by the differentials offered to them in the new contract but there will be work well beyond 38 hours a week to be done in the Health Service for the foreseeable future. So consultants on the C.C.H.M.S.'s "defined contract" for 10 sessions not wanting to do independent practice outside the N.H.S. should still receive a considerable boost to their income by continuing with their present weekly workload. No firm figures, however, can be attached to either set of contract proposals because under present arrangements the Review Body would decide the price tag.

A contract sensitive to all the diversities of N.H.S. hospital work is probably unattainable. But the substantial support senior hospital staff gave to the C.C.H.M.S. Contract (7 December, p. 608) and the fact that by Christmas over 6000 consultants had registered with the B.M.A.'s employment agencies point clearly to doctors' preferences.

But even if the Government's contract means that wholetime consultants might get more than a universal ten-session contract could provide, are its terms worth accepting ? The B.M.A. and the H.C.S.A. think not. Firstly, and pragmatically, today's financial advantage can be quickly wiped out. Secondly, the profession's future negotiating power would be permanently crippled. But finally, and most serious, is the threat to the professional independence of all doctorssomething which the architect of the N.H.S., Mr. Aneurin Bevan, was careful to leave intact. In an increasingly institutionalized world this is an appreciating asset for all the community. Mrs. Barbara Castle seems set on suppressing it. Is she really so indifferent to the welfare of British medicine? 